\title{
Graft Copolymerization of Acrylonitrile onto Torch Ginger Cellulose
}

\author{
(Pengkopolimeran Cangkuk Akrilonitril ke atas Selulosa Kantan)
}

\author{
FAZLIYANA AHMAD ZAKI \& IBRAHIM ABDULLAH*
}

\begin{abstract}
Graft copolymerization of acrylonitrile onto torch ginger cellulose was carried out in an aqueous medium with ceric ion redox initiator. The optimum grafting parameters such as temperature, reaction time, ratio of monomer to cellulose addition and ceric ammonium nitrate (CAN) concentration were determined and a maximum graft yield of $40 \%$ was recorded. The graft copolymer was characterized and compared with untreated cellulose. A new absorption peak corresponding to the nitrile group of acrylonitrile was recorded by FTIR at $2244 \mathrm{~cm}^{-1}$ on the grafted cellulose. The morphology studies showed that the diameter and the surface roughness of grafted cellulose had increased as compared with the untreated cellulose. On the contrary, the grafting had resulted in lowering the crystallinity of the cellulose from 63 to $53 \%$. The grafted cellulose produced a new derivative TG peak at $420^{\circ} \mathrm{C}$ and higher residual percentage than the untreated cellulose.
\end{abstract}

Keywords: Acrylonitrile; cellulose; graft copolymerization; torch ginger

\section{ABSTRAK}

Pengkopolimeran cangkuk monomer akrilonitril ke atas selulosa telah dijalankan di dalam medium akuas dengan pemula redoks ion serik. Parameter cangkukan optimum seperti suhu, tempoh tindak balas, nisbah penambahan monomer kepada selulosa dan kepekatan serik amonium nitrat (CAN) telah ditentukan dengan hasil cangkukan maksimum sebanyak $40 \%$ telah direkodkan. Kopolimer cangkuk dicirikan dan perbandingan dilakukan dengan selulosa tanpa rawatan. Puncak serapan baru FTIR pada selulosa tercangkuk telah dirakam pada $2244 \mathrm{~cm}^{-1}$ yang merujuk kepada kumpulan nitril daripada akrilonitril. Kajian morfologi menunjukkan diameter dan kekasaran permukaan selulosa tercangkuk telah bertambah jika dibandingkan dengan selulosa tanpa rawatan. Sebaliknya, proses cangkukan telah mengakibatkan berlakunya penurunan kehabluran selulosa daripada 63 kepada 53\%. Selulosa tercangkuk didapati telah menghasilkan puncak terbitan TG baru pada $420^{\circ} \mathrm{C}$ dengan peratus residu yang lebih tinggi daripada selulosa tanpa rawatan.

Kata kunci: Akrilonitril; kantan; pengkopolimeran cangkuk; selulosa

\section{INTRODUCTION}

The increasing awareness on environmental friendly products has led to the development of natural fibres as thermoplastic reinforced fillers. Even though the mechanical strength of natural fibres is as good as synthetic materials, their hydrophilic nature must be overcome to reduce surface tension with the hydrophobic thermoplastic matrix. Modifications such as silane treatment, acetylation, mercerization and graft copolymerization had been reported (Bledzki et al. 2008; Cao et al. 2006; Raquez et al. 2012). Among the various methods reported, graft copolymerization is an attractive method to impart a variety of functional groups on the polymer backbone.

Graft copolymerization is a process in which side chain grafts are covalently bonded to the main chain of a polymer backbone to form branched copolymer (Dahou et al. 2010). It provides a potential route for altering the physical and chemical properties of cellulose without affecting the cellulose basic properties (Kumar et al. 2011). Depending on the chemical structure of monomer, modified cellulose through grafting may acquire new properties such as hydrophobic or hydrophilic character, thermal resistivity, microbe and fungal resistivity and ion-exchange capability (Dahou et al. 2010). In view of altering the hydrophilicity of cellulose, a number of hydrophobic monomers such as methyl methacrylate, styrene, acrylonitrile and vinyl acetate had been used as modifiers. Graft copolymerization can be done via irradiations (such as ultraviolet and gamma) or conventional chemical syntheses, with better advantages on the latter due to high radical yield and no cellulosic chain degradation (Thakur et al. 2011). The use of ceric ammonium salt as initiator was reported to give a high grafting efficiency with minimum side reaction and mild grafting conditions (Bhattacharya \& Misra 2004).

Torch ginger or Etlingera elatior is a herbaceous perennial plant cultivated abundantly in Malaysia. The stem of the plant is non woody, fibrous and mostly left as agricultural waste. It was made up of $65 \%$ cellulose, $10 \%$ hemicellulose, $19 \%$ lignin and 4\% extractives as reported in previous work (Zaki et al. 2014). As compared to the raw fibres, the extracted cellulose was chosen in this study due to better physical and chemical properties after the removal of lignin and hemicellulose (Reddy \& Yang 2009). 
The present work reported the synthesis of cellulose copolymer with acrylonitrile initiated by CAN. The grafting of hydrophobic acrylonitrile monomer onto the extracted cellulose from torch ginger fibre was carried out in aqueous solution. The modification was expected to focus on the amorphous component of the cellulose. The optimum grafting conditions were determined and the grafted cellulose produced was characterized.

\section{MATERIALS AND METHODS}

\section{MATERIALS}

Torch ginger stem used in the present study was obtained from local sources in Selangor, Malaysia. Sodium chlorite $\left(\mathrm{NaClO}_{2}\right)$, acrylonitrile monomer $(99 \%)$, ceric ammonium nitrate and nitric acid were supplied by Sigma Aldrich while sodium hydroxide $(\mathrm{NaOH}), \mathrm{N}, \mathrm{N}$-dimethylformamide (DMF) and methanol were supplied by Systerm. All chemicals were ChemAR grade except sodium chlorite (technical grade). Acrylonitrile was distilled prior to use while others were used as received.

\section{CELLULOSE EXTRACTION}

The matured torch ginger stems were cut vertically into half and the soft, inner stems were removed. The stems were dried and ground using a mill. The fibres were graded and treated with 4 wt. $\%$ of $\mathrm{NaOH}$ solution at $90^{\circ} \mathrm{C}$ for 2 $\mathrm{h}$. The fibres were stirred under mechanical stirring with fibre to liquor ratio 1:20. The mixtures were washed with excess distilled water in order to remove the impurities and neutralize the fibres. The treatment was repeated and subsequent bleaching treatment was carried out by using $1.7 \% \mathrm{w} / \mathrm{v} \mathrm{NaClO}_{2}$ and acetate buffer solution $(\mathrm{pH} 4)$ at $90^{\circ} \mathrm{C}$ for $4 \mathrm{~h}$. The extracted cellulose was washed again and the process was repeated to produce white coloured cellulose.

\section{GRAFT COPOLYMERIZATION}

$10 \mathrm{~g}$ of cellulose was placed in a 3-necked flask. Fifty $\mathrm{mL}$ of distilled water was added and stirred. The flask was equipped with a nitrogen gas inlet and a reflux condenser immersed in a constant temperature water bath. Nitrogen gas was bubbled for $1 \mathrm{~h}$ at a desired temperature (30$50^{\circ} \mathrm{C}$ ). A freshly prepared $10 \mathrm{~mL}$ solution of CAN (8.3$25.0 \mathrm{mmol} / \mathrm{L}$ ) in $0.1 \mathrm{~mol} / \mathrm{L}$ nitric acid was added and stirred for $10 \mathrm{~min} . \mathrm{N}_{2}$ was purged continuously through the reaction mixture and acrylonitrile (0.5-3.0 g) was added. The grafting reaction was carried out for varying time (1-4 h). After completion, the mixture was washed with distilled water and subsequently with methanol. The crude copolymer product was dried in oven to a constant weight at $60^{\circ} \mathrm{C}$. Homopolymer was then removed through soxhlet extraction with DMF for $24 \mathrm{~h}$. Grafted cellulose was washed with methanol and dried to a constant weight. The percentage and efficiency of grafting were calculated according to the following equations (Tosh \& Routray 2011).

$$
\begin{aligned}
& \% \text { Grafting }(\% \mathrm{GY})=\frac{C-A}{A} \times 100 \\
& \% \text { Grafting Efficiency }(\% \mathrm{GE})=\frac{C-A}{B-A} \times 100,
\end{aligned}
$$

where A is the weight $(\mathrm{g})$ of the original cellulose, $B$ is the weight of the grafted cellulose before homopolymer extraction and $\mathrm{C}$ is the weight of the grafted product after homopolymer extraction.

Grafted cellulose with optimum graft efficiency was characterized and compared with the extracted torch ginger cellulose.

\section{ANALYSIS}

\section{SURFACE ANALYSIS}

Surface morphology of cellulose and grafted cellulose were observed by using variable pressure scanning electron microscope model Leo $1450 \mathrm{VP}$ with $20 \mathrm{kV}$ electron beam at $1000 \times$ magnification. The fibres were laid down on the aluminium stub using a conductive tape and were coated with gold.

\section{SPECTROSCOPIC ANALYSIS}

The cellulose and grafted cellulose were analyzed through FTIR spectroscopy by using a Perkin Elmer FTIR spectrophotometer model GX to characterize the functional groups in the sample. A transparent pallet was prepared with $\mathrm{KBr}$ and the spectrum was scanned through with wave numbers ranges from 400 to $4000 \mathrm{~cm}^{-1}$.

\section{X-RAY DIFFRACTION}

XRD model D8-Advance Bruker AXS with $\mathrm{CuK} \alpha$ radiation $(\lambda=0.1539 \mathrm{~nm})$ was used to study the crystallinity of the fibre. The data was collected in a $2 \theta$ range $10^{\circ}-50^{\circ}$. Each sample was ground and evenly distributed in the sample holder. Percent crystallinity $\left(\% \mathrm{X}_{\mathrm{Cr}}\right)$ of cellulose and grafted cellulose were calculated by using the following equation,

$$
\% \mathrm{X}_{\mathrm{Cr}}=\frac{\mathrm{I}_{002}}{\left(I_{002}-I_{a m}\right)} \times 100,
$$

where $\mathrm{I}_{002}$ is the maximum intensity of the crystalline peak located at $2 \theta$ angle close to $22^{\circ}$ and the intensity scattered by the amorphous part $\left(\mathrm{I}_{\mathrm{am}}\right)$ is measured at $2 \theta$ angle close to $15^{\circ}$.

\section{THERMAL ANALYSIS}

Thermogravimetric analysis (TGA) and differential thermal analysis (DTG) thermograms of cellulose and grafted cellulose were carried out in nitrogen atmosphere on thermal analyzer Mettler Toledo TGA/SDTA 85-F at heating rate of $10^{\circ} \mathrm{C} / \mathrm{min}$. The studies were performed over a temperature range of 25 to $600^{\circ} \mathrm{C}$ in nitrogen atmosphere with a flow rate at $20 \mathrm{~mL} / \mathrm{min}$. 


\section{RESULTS AND DISCUSSION}

\section{OPTIMUM REACTION CONDITIONS}

Reaction Time The effects of reaction time intervals on the percentage of grafting yield (\%GY) and grafting efficiency (\%GE) are shown in Figure 1. The \%GY increases with time and reaches a maximum value at $3 \mathrm{~h}$ duration. As the time increases, interactions between Ce(IV) ions and cellulose backbone increased, resulting in the increased \%GY. Beyond the optimum time, most of the active sites on the backbone are occupied by the radicals and the formation of the homopolymer dominates over graft copolymerization. Besides that, as the reaction time getting longer, the reaction medium became more viscous (Thakur et al. 2011), thus providing hindrance for radicals to move onto the active sites and resulted in decreasing \%GY and \%GE.

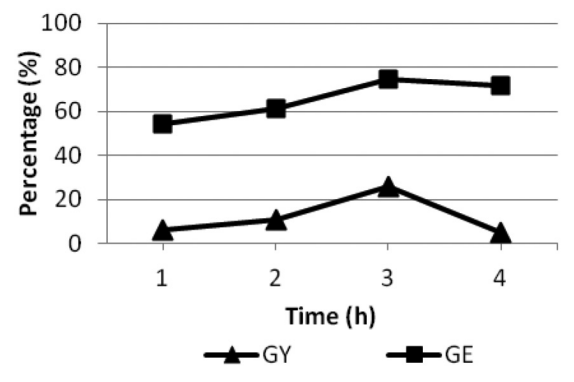

FIGURE 1. Effect of reaction time

CAN Concentration The optimum initiator concentration for the maximum $\% \mathrm{GY}$ and $\% \mathrm{GE}$ was found to be 16.7 $\mathrm{mmol} / \mathrm{L}$ (Figure 2). As the CAN concentration increases, more $\mathrm{Ce}(\mathrm{IV})$ ions are produced which result in the generation of more reactive sites on the fibre backbone and monomer radicals. Hence \%GY increases with the initial rise in initiator concentration. After reaching the optimum yield $(26 \%), \%$ GY decreases with further increase in CAN concentration. This might be due to the termination of growing polymeric chains taking place and homopolymer formation competes with grafting reaction for the available monomer (Kumar et al. 2011).

Temperature The \%GY increases with the initial increase of temperature, reaches the optimum value $40 \%$ at $40^{\circ} \mathrm{C}$

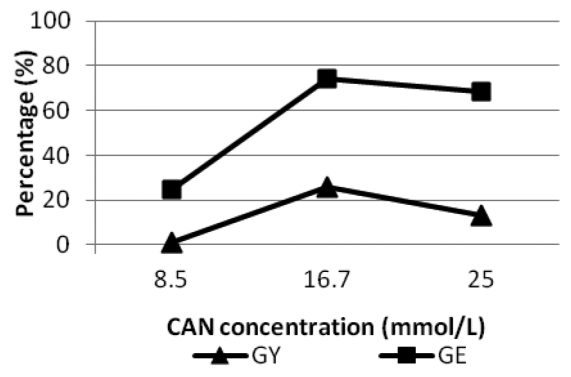

FIGURE 2. Effect of CAN concentration and then decreases beyond this temperature (Figure 3 ). As the temperature increases, the kinetic energy of the molecules increases and more radicals moving at faster rates, resulting in more collisions and thus increase \%GY with maximum efficiency of $89 \%$. However, beyond the optimum temperature, the $\% \mathrm{GY}$ and $\% \mathrm{GE}$ decrease significantly due to the increase formation of homopolymer on increasing the temperature.

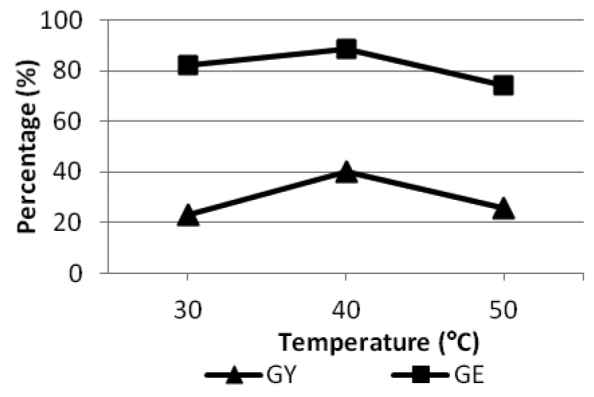

FIGURE 3. Effect of temperature

Monomer/Cellulose Ratio Figure 4 shows the \%GY increases with the increased of monomer/cellulose addition ratio. The increase in monomer had increased the number of monomer radicals, which caused an increased in $\% \mathrm{GY}$. Although \% GY is continuously increased, the $\%$ GE decreases beyond 1:1 ratio. At a higher ratio, the monomer was less reactive towards the graft formation. The increase of $\%$ GY beyond the optimum ratio might be due to the termination of the reactive monomer or radical sites. It happened as the rate of combination and disproportionation of monomer radicals are faster than that of their combination with cellulose radicals thus favouring the formation of homopolymer (Mondal et al. 2003).

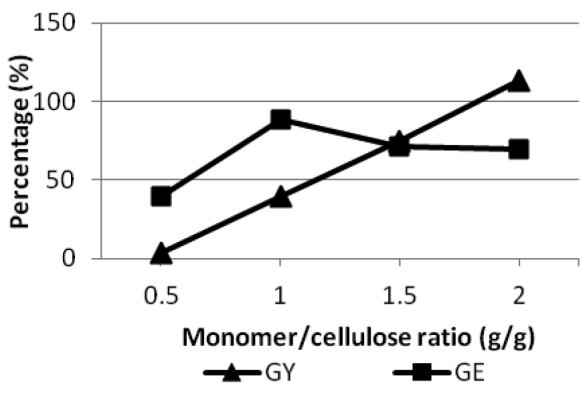

FIGURE 4. Effect of monomer/cellulose ratio

Reaction Conditions of Graft Copolymerization of Cellulose When cellulose is oxidized by CAN salt, free radicals are formed on the cellulose by a single electron transfer process (Hebeish \& Guthrie 1981). The initiation reaction is assumed to involve the oxidation of cellulose to form an intermediate complex between $\mathrm{Ce}(\mathrm{IV})$ ion and the 
cellulose as shown in Scheme 1 (Goyal et al. 2009). It is proposed that the oxidation of $\mathrm{Ce}(\mathrm{IV})$ with cellulose will occur preferably at the $\mathrm{C}_{2}-\mathrm{C}_{3}$ glycol in anhydroglucose unit rather than the $\mathrm{C}_{6}$ primary hydroxyl (Roy et al. 2009). This is followed by the disproportionation of the complex to form radicals on the cellulose molecule at either $\mathrm{C}_{2}$ or $\mathrm{C}_{3}$ position. The free radical reacts with the acrylonitrile monomer which is present in the reaction mixture to initiate graft copolymerization.

Two pathways are envisaged for radical $\left(\mathrm{M}^{*}\right)$ that is grafting on the cellulose backbone and formation of homopolymer. These two pathways are competing with each other as the grafting process is more favourable path at optimum conditions than the formation of homopolymer.

Fourier-Transform Infra Red Spectra Figure 5 shows the FTIR spectra for cellulose and grafted cellulose. The grafted cellulose retains the cellulose peaks at 3370-3350, 2910-2890 and $1660-1640 \mathrm{~cm}^{-1}$ that corresponded to stretching of $-\mathrm{OH},-\mathrm{CH}$ and water absorbed in the fibre. The peaks at 1430,1372, 1059 and $890 \mathrm{~cm}^{-1}$ are attributed to $-\mathrm{CH}_{2}$ bending, $-\mathrm{CH}_{3}$ bending, $\mathrm{C}-\mathrm{O}$ stretching and $-\mathrm{CH}$ vibration in carbohydrate (Alemdar \& Saim 2008). In
Figure 5(b), there is an additional peak observed at 2244 $\mathrm{cm}^{-1}$ peak. This single sharp peak is associated to the $-\mathrm{CN}$ vibration in nitrile functional group, indicating the presence of polyacrylonitrile (PAN) (Dahou et al. 2010).

Morphological Studies Micrograph on Figure 6(a) showed a smooth surface of cellulose fibre. Meanwhile, rough surface were observed on the grafted cellulose (Figure 6(b)) indicating the deposition of PAN. Fan et al. (2006) reported that the adhesion of the grafted fibres to other materials improved with the surface roughness because of an increase in surface area for bonding and mechanical interlocking. Therefore, this would give benefit in improving the adhesion of grafted fibres to the matrix polymers hence improving the mechanical performance of composites. In addition, the average diameter of the grafted cellulose was found to increase from 12 to $16 \mu \mathrm{m}$. As the reaction took place in aqueous system, hydroxyl groups of cellulose could interact with water through hydrogen bonding and led to fibre swelling and structure opening (Thakur et al. 2011). This makes cellulose accessible to the deposition of monomer and polymer chains growth thus resulting in increased average diameter.

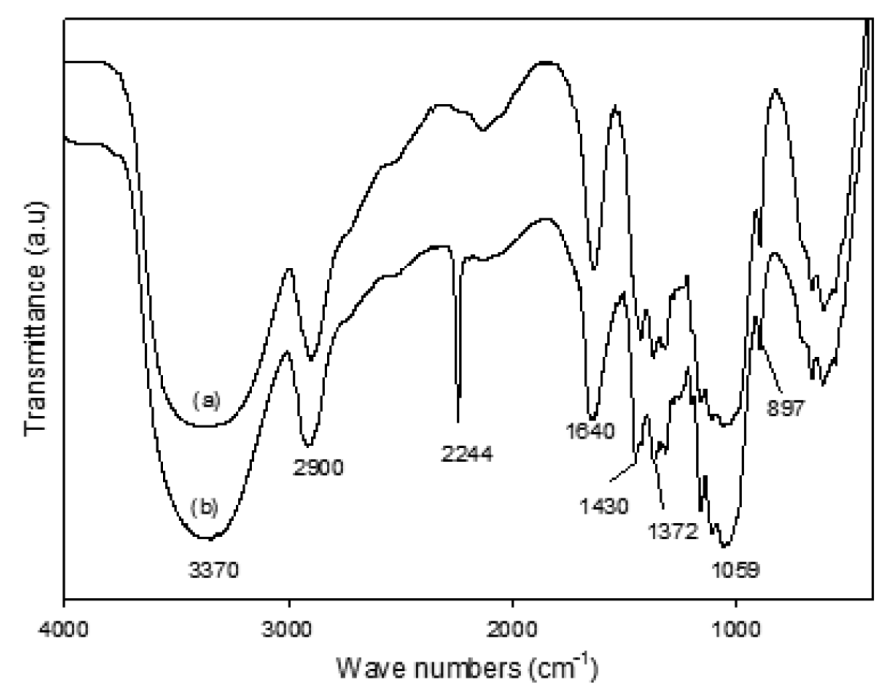

FIGURE 5. FTIR spectra of (a) cellulose and (b) grafted cellulose

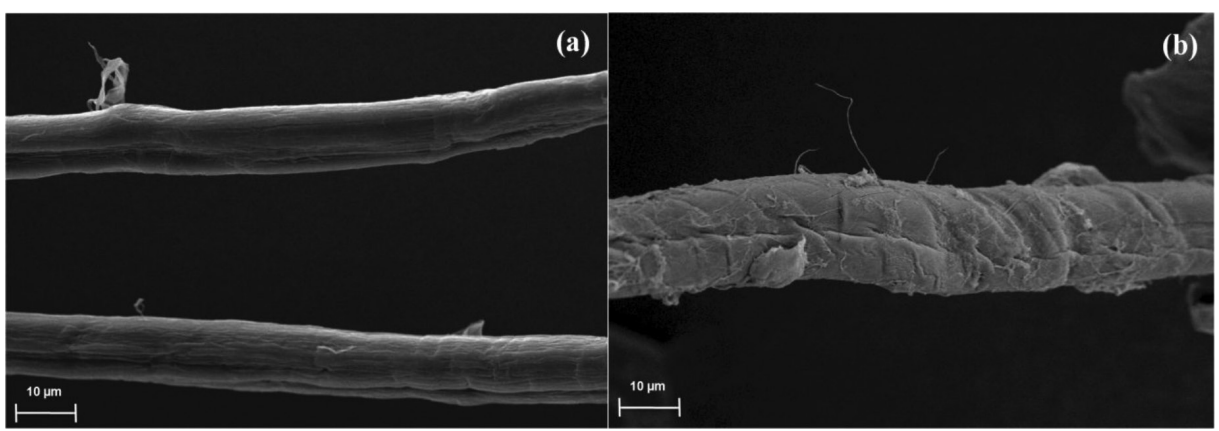

FIGURE 6. SEM images of a) cellulose fibre and b) grafted cellulose 
$X$-Ray Diffraction Figure 7 exhibits the XRD diffractograms of cellulose and the graft copolymer. The diffraction pattern of torch ginger cellulose shows a sharp peak with high intensity whereas the acrylonitrile grafted sample shows a decrease intensity and broader peak. The calculated crystallinity percentage of the original cellulose is higher than the grafted cellulose. This shows that the fiber crystallinity is affected by the graft copolymerization. Grafting caused the cellulose chain to be less flexible that led to lowering the degree of freedom of motion. According Singha and Rana (2010) grafting of monomer onto the cellulose backbone had impaired the fibre crystallinity due to increasing amorphous region of the fibre, thus resulting in reduced $\% \mathrm{X}_{\mathrm{Cr}}$.

Thermal Analysis Figure 8 shows the TG and DTG curves for both cellulose and grafted cellulose. At temperatures below $100^{\circ} \mathrm{C}$, an initial weight loss in cellulose is observed due to the moisture evaporation. The main degradation of cellulose occurs with $81.7 \%$ weight loss recorded at $250-350^{\circ} \mathrm{C}$. Final products of cellulose degradation are mainly of carbonaceous and inorganic compounds with a total residual of $12.9 \%$. As compared to cellulose, 4 decomposition stages were observed for the grafted cellulose. The early stage is associated with the moisture evaporation with lesser weight loss recorded due to the reduced hydrophilicity of the copolymer. The decomposition of polyacrylonitrile consisted of ammonia, HCN, acrylonitrile and acrylonitrile oligomers (Surianaryanan et al. 1998). At temperatures below the cellulose degradation, $6.8 \%$ weight loss corresponding to acrylonitrile is recorded. According to Badawy et al. (2001), the pyrolysis of polyacrylonitrile removes the graft polyacrylonitrile side chain at $240^{\circ} \mathrm{C}$. The same trend of decomposition peak at $350^{\circ} \mathrm{C}$ from the grafted cellulose indicates that it belongs to the untreated cellulose as the optimum's graft yield is $40 \%$. A new decomposition peak at $420^{\circ} \mathrm{C}$ is observed and probably is associated with the grafted cellulose that degraded later than cellulose. About $43.4 \%$ residual is recorded for the copolymer. This high residual value might be due to the remaining polyacrylonitrile that decomposed at higher temperature $\left(>600^{\circ} \mathrm{C}\right)$.

\section{CONCLUSION}

Surface modification through grafting with acrylonitrile onto cellulose can be initiated effectively with CAN. The optimized reaction conditions obtained for the graft copolymerization were: CAN concentration $16.7 \mathrm{mmol} / \mathrm{L}$, reaction time $3 \mathrm{~h}$, temperature $40^{\circ} \mathrm{C}$ and monomer/ cellulose addition ratio $1: 1$. The $\% \mathrm{GY}$ and $\% \mathrm{GE}$ for the optimized sample are $40.0 \%$ and $88.9 \%$, respectively. A new FTIR peak was recorded at $2244 \mathrm{~cm}^{-1}$ suggesting the presence of PAN in the copolymer. The grafted cellulose was observed with rougher surface and increased average

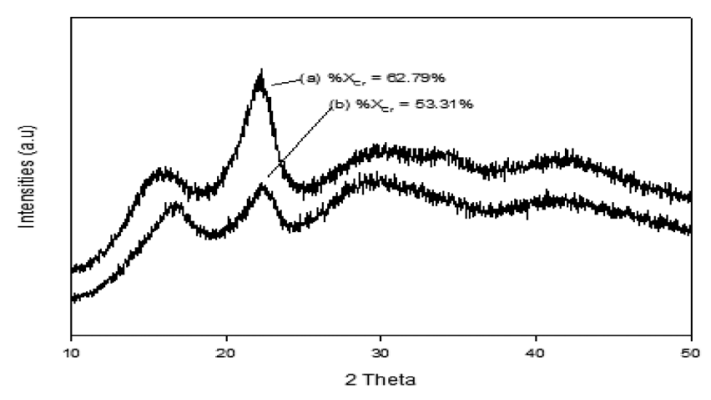

FIGURE 7. XRD patterns and crystallinity percentage of (a) cellulose and (b) grafted cellulose
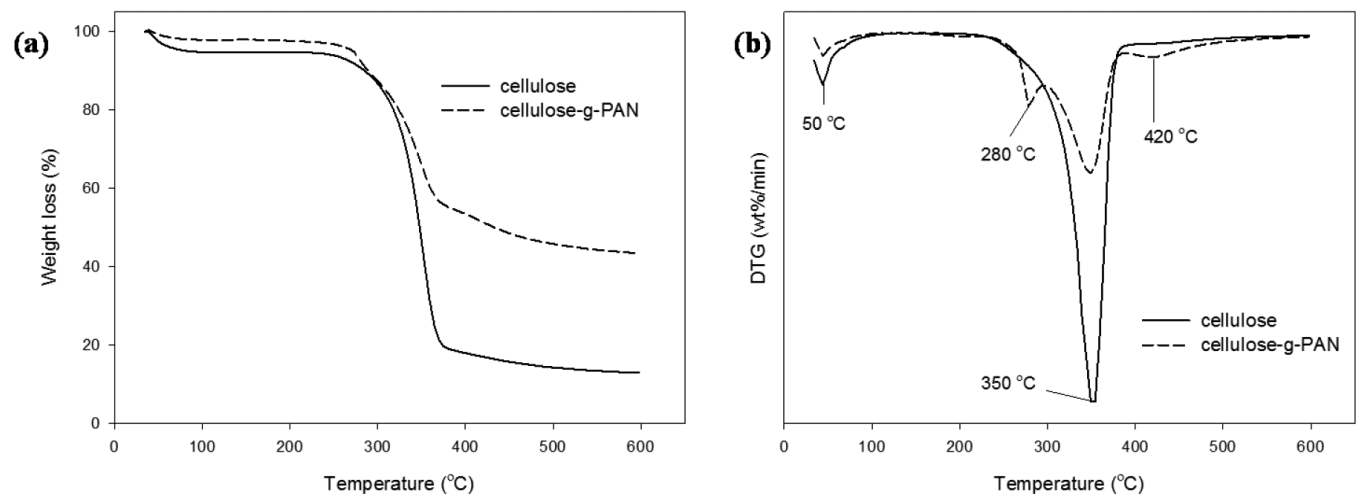

FIGURE 8. (a) TGA and (b) DTG curves of cellulose and grafted cellulose 
diameter than the untreated cellulose. The deposition of PAN on the fibre had resulted in reduced crystallinity of the grafted cellulose with $53 \%$ in comparison with the untreated cellulose (63\%). However, as compared to the untreated, the grafted cellulose was found to produce a new derivative curve with higher residual percentage recorded.

\section{ACKNOWLEDGEMENTS}

The authors would like to extend their gratitude towards Universiti Kebangsaan Malaysia and Polymer Research Center (PORCE) for allowing this research to be carried out and scholarship support. Thank you to the Centre for Research and Instrumentation Management (CRIM) for the instrumentation services (VPSEM \& XRD) provided.

\section{REFERENCES}

Alemdar, A. \& Sain, M. 2008. Isolation and characterization of nanofibers from agricultural residue - wheat straw and soy hulls. Bioresources Technology 99: 1664-1671.

Badawy, S.M., Dessouki, A.M. \& El-Din, H.M.N. 2001. Direct pyrolysis mass spectrometry of acrylonitrile-cellulose graft copolymer prepared by radiation-induced graft polymerization in presence of styrene as homopolymer suppressor. Radiation Physics and Chemistry 61: 143-148.

Bledzki, A.K., Mamun, A.A., Lucka-Gabor, M. \& Gutowski, V.S. 2008. The effects of acetylation on properties of flax fibre and its polypropylene composites. Express Polymer Letters 2: 413-422.

Bhattacharya, A. \& Misra, B.N. 2004. Grafting: A versatile means to modify polymers. Techniques, factors and applications. Progress in Polymer Science 29: 767-814.

Cao, Y., Shibata, S. \& Fukumoto, I. 2006. Mechanical properties of biodegradable composites reinforced with bagasse fibre before and after alkali treatments. Composites: Part A 37: 423-429.

Dahou, W., Ghemati, D., Oudia, A. \& Aliouche, D. 2010. Preparation and biological characterization of cellulose graft copolymers. Biochemical Engineering Journal 48: 187-194.

Fan, G., Zhao, J., Zhang, Y. \& Guo, Z. 2006. Grafting modification of Kevlar fiber using horseradish peroxidase. Polymer Bulletin 56: 507-515.

Goyal, P., Kumar, V. \& Sharma, P. 2009. Graft copolymerization onto tamarind kernel powder: Ceric(IV)-initiated graft copolymerization of acrylonitrile. Journal of Applied Polymer Science 114: 377-386.

Hebeish,A.\& Guthrie, J.T. 1981. The Chemistry and Technology of Cellulosic Copolymers. Berlin: Springer-Verlag.
Kumar, V., Naithani, S. \& Pandey, D. 2011. Optimization of reaction conditions for grafting of $\alpha$-cellulose isolated from Lantana camara with acrylamide. Carbohydrate Polymers 86: 760-768.

Mondal, M.I.H., Alam, R. \& Sayeed, M.A. 2003. Graft copolymerization of nitrile monomers onto bleached jute fiber using potassium persulfate system and their textile characteristics. Journal of Applied Polymer Science 92: 3622-3629.

Raquez, J.M., Murena, Y., Goffin, A.L., Habibi, Y., Ruelle, B., DeBuyl, F. \& Dubois, P. 2012. Surface-modification of cellulose nanowhiskers and their use as nanoreinforcers into polylactide: A sustainably-integrated approach. Composites Science and Technology 72: 544-549.

Reddy, N.\& Yang, Y. 2009. Properties and potential applications of natural cellulose fibers from the bark of cotton stalks. Bioresource Technology 100: 3563-3569.

Roy, D., Semsarilar, M., Guthrie, J.T. \& Perrier, S. 2009. Cellulose modification by polymer grafting: A review. Chemical Society Reviews 38: 1825-2148.

Singha, A.S. \& Rana, R.K. 2010. Effect of pressure induced graft copolymerization on the physic-chemical properties of bio-fibers. Bioresources 5: 1055-1073.

Surianaryanan, M., Vijayaraghavan, R. \& Raghavan, K.V. 1998. Spectroscopic investigations of polyacrylonitrile thermal degradation. J. Polym. Sci. A: Polym. Chem. 36: 2503.

Thakur, V.K., Singha, A.S. \& Misra, B.N. 2011. Graft copolymerization of methyl methacrylate onto cellulosic biofibers. Journal of Applied Polymer Science 122: 532-544.

Tosh, B. \& Routray, C.R. 2011 . Homogeneous grafting of PMMA onto cellulose in presence of $\mathrm{Ce}^{4+}$ as initiator. Indian Journal of Chemical Technology 18: 234-243.

Zaki, F.A., Abdullah, I. \& Ahmad, I. 2014. The physical and chemical natures of cellulose extracted from torch ginger stems. Int. J. Materials Engineering Innovation 5: 48-60.

Faculty of Science and Technology

Universiti Kebangsaan Malaysia

43600 Bangi, Selangor Darul Ehsan

Malaysia

*Corresponding author; email: dia@ukm.edu.my

Received: 15 January 2014

Accepted: 15 November 2014 
(a) Complex formation

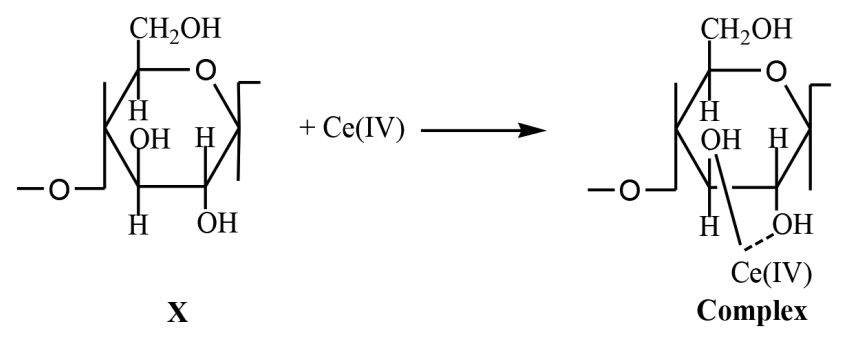

(b) Chain initiation

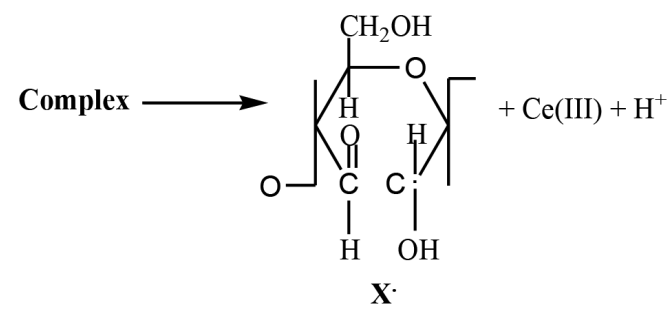

\section{(c) Chain propagation}

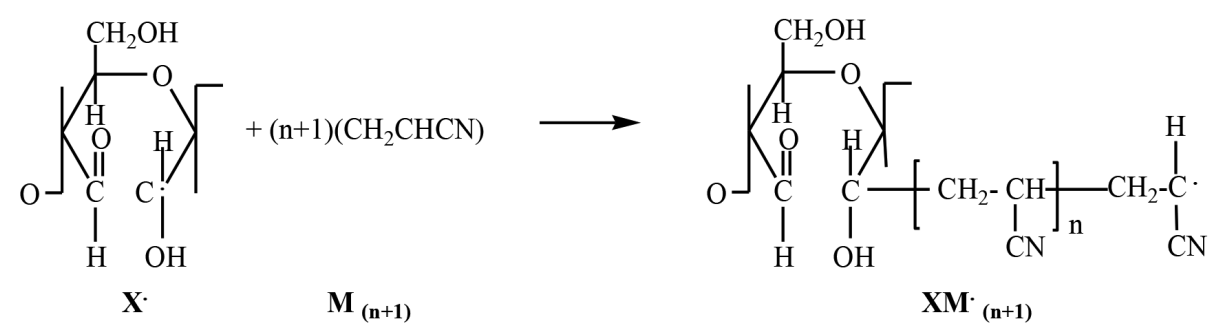

\section{(d) Chain termination}

$$
\begin{aligned}
& \mathrm{XM}_{(\mathrm{n}+1)}+\mathrm{XM}_{(\mathrm{n}+1)} \longrightarrow \text { Graft copolymer } \\
& \mathrm{M}_{(\mathrm{n}+1)}+\mathrm{M}_{(\mathrm{n}+1)} \longrightarrow \text { Homopolymer } \\
& \mathrm{XM}_{(\mathrm{n}+1)}+\mathrm{M}_{(\mathrm{n}+1)} \longrightarrow \text { Graft copolymer }
\end{aligned}
$$

SCHEME 1. The proposed grafting mechanism (Goyal et al. 2009) 